\title{
Effect of cytokinins on shoot proliferation of silver birch (Betula pendula) in tissue culture
}

\author{
Elva Girgžde', Ineta Samsone ${ }^{2 *}$ \\ ${ }^{1}$ Faculty of Biology, University of Latvia, Jelgavas 1, Rīga LV-1004, Latvia \\ ${ }^{2}$ Latvian State Forest Research Institute "Silava”, Rīgas 111, Salaspils LV-2169, Latvia. \\ ${ }^{\star}$ Corresponding author, E-mail: ineta.samsone@silava.lv
}

\begin{abstract}
Micropropagation can be used as an alternative method for vegetative propagation of mature birch trees in order to increase effectiveness of breeding. In this study the optimal concentration of synthetic cytokinin 6-benzylaminopurine and naturally occurring cytokinin zeatin were determined for shoot proliferation of birch genotype Bau-40-17. Woody Plant Medium supplemented with 6-benzylaminopurine or zeatin at three different concentrations was used. The results showed that Woody Plant Medium supplemented with 1.0 mg $\mathrm{L}^{-1}$ 6-bezylaminopuryne gave the best results for shoot multiplication. In the case of natural cytokinin zeatin, $1.0 \mathrm{mg} \mathrm{L}^{-1}$ with addition of $0.1 \mathrm{mg} \mathrm{L}^{-1}$ kinetin gave the best results, but proliferation rate was significantly lower than with synthetic cytokinin. The presence of cytokinin in the medium affected adventitious root formation and resulted in change of $\mathrm{pH}$, which may have caused a positive effect on shoot multiplication rate.
\end{abstract}

Key words: Betula pendula, cytokinins, shoot culture, shoot multiplication.

Abbreviations: BAP, 6-bezylaminopurine; IAA, indole-3-acetic acid; IBA, indole-3-butyric acid; MS, Murashige and Skoog's; NAA, 1-naphthaleneacetic acid; TDZ, thidiazuron; WPM, Woody Plant Medium.

\section{Introduction}

Silver birch (Betulapendula L.) is an economically important tree species in several European countries including Latvia. High demand of birch wood puts greater emphasis on breeding and establishment of qualitative forest stands. The breeding cycle can be shortened by 10 to 15 years when vegetative propagation of birch is used, thereby greatly increasing effectiveness of breeding (Ewald et al. 2002). Mature birch trees are difficult to propagate by classical vegetative propagation methods, but micropropagation can be used as an alternative to produce clonal material (Ryynänen, Ryynänen 1986; Welander 1993).

Plant growth regulators are the most important factors affecting shoot proliferation in tissue culture (Van Staden et al. 2008). Synthetic cytokinin 6-bezylaminopurine (BAP), kinetin and thidiazuron (TDZ) are the most widely used plant growth regulators for shoot multiplication. Auxins are also required in order to achieve optimal shoot growth and morphogenesis (Van Staden et al.2008). The most frequently used auxins are indole-3-acetic acid (IAA), indole-3butyric acid (IBA) and 1-naphthaleneacetic acid (NAA). Both nutrient media and type and concentration of plant growth regulators used for birch shoot multiplication varies in different studies. In most of the birch micropropagation protocols Lloyd and McCown (1980) Woody Plant Medium (WPM) or modified Murashige and Skoog's (1962) (MS) nutrient medium supplemented with cytokinins was used for shoot multiplication. BAP concentration used in multiplication medium usually is from 0.1 to $10.0 \mathrm{mg} \mathrm{L}^{-1}$ (McCown, McCown 1987; Särkilahti 1988; Jokinen et al. 1991). Chalupa (1981) used BAP at concentration 0.4 and $0.6 \mathrm{mg} \mathrm{L}^{-1}$ for bud induction from shoot tips and found that kinetin was less effective in formation of new tissue than BAP. Ryynänen and Ryynänen (1986) used 10.0 BAP $\mathrm{mg} \mathrm{L}^{-1}$ and $0.2 \mathrm{mg} \mathrm{L}^{-1} \mathrm{NAA}$ for curly birch (B. pendula var. carelica) adventitious bud induction and $0.5 \mathrm{mg} \mathrm{L}^{-1} \mathrm{BAP}$ and $0.5 \mathrm{mg} \mathrm{L}^{-1}$ IAA for induced shoot development. For propagation of Betula platyphylla and Betula papyrifera, BAP at concentration from 2 to $5 \mathrm{mg} \mathrm{L}^{-1}$ and TDZ from 0.8 to $1.7 \mathrm{mg} \mathrm{L}^{-1}$ produced about four shoots per explant (Magnusson et al. 2009). In presence of BAP $0.6 \mathrm{mg} \mathrm{L}^{-1}$, shoots of Betula celtiberica formed bud clusters of 20 to 50 plantlets per explant (Perez, Postigo 1989). The best shoot multiplication media (natural cytokinin $1.0 \mathrm{mg} \mathrm{L}^{-1}$ zeatin and $0.1 \mathrm{mg} \mathrm{L}^{-1}$ kinetin) for B. pendula and Betula pubescens showed multiplication rate 3 and has been used as standard birch micropropagation protocol (O’Dowd 2004). Dubova (1994) obtained both adventitious and axillary shoots from seeds and young seedlings using $0.5 \mathrm{mg} \mathrm{L}^{-1} \mathrm{BAP}$ with additional $0.05 \mathrm{mg} \mathrm{L}^{-1} \mathrm{IBA}$ or $0.001 \mathrm{mg} \mathrm{L}^{-1}$ NAA.

However, additional work must be done for optimization of multiplication medium for propagation of trees of particular birch genotypes. Therefore, the aim of the present 
study was to determine the optimal concentration of synthetic cytokinin BAP and naturally occurring cytokinin zeatin for birch genotype Bau-40-17 shoot multiplication.

\section{Materials and methods}

Open pollinated seeds from phenotypically selected plustrees were collected in 1995 from a birch forest stand in the western reproductive district of Latvia near Bauska. A progeny trial in region of Kegums was established from the collected seeds in 1999. Bau-40-17 was determined as one of the best clones according to different parameters of trunk and branches, and in vitro culture for this clone was established in the State Forest Research Institute "Silava", Latvia.

Approximately $1.5-\mathrm{cm}$-long shoot tips were used for initiation of new culture for the experiments. Macronutrients, micronutrients and vitamins were used according to Woody Plant Medium (WPM) (Lloyd, McCown, 1980) with additional $20 \mathrm{~g} \mathrm{~L}^{-1}$ sucrose and $6 \mathrm{~g} \mathrm{~L}^{-1}$ agar. Seven different multiplication media supplemented with synthetic cytokinin BAP, kinetin and naturally occurring cytokinin zeatin were tested: (1) without plant growth regulators; (2) $0.25 \mathrm{mg} \mathrm{L}^{-1} \mathrm{BAP}$; (3) $0.5 \mathrm{mg} \mathrm{L}^{-1} \mathrm{BAP}$; (4) $1.0 \mathrm{mg} \mathrm{L}^{-1} \mathrm{BAP}$; (5) $0.5 \mathrm{mg} \mathrm{L}^{-1}$ zeatin; (6) $1.0 \mathrm{mg} \mathrm{L}^{-1}$ zeatin; and (7) $1.0 \mathrm{mg} \mathrm{L}^{-1}$ zeatin with $0.1 \mathrm{mg} \mathrm{L}^{-1}$ kinetin. Media $\mathrm{pH}$ were adjusted to 5.8 , then autoclaved for $15 \mathrm{~min}$ $\left(110 \mathrm{kPa}, 121^{\circ} \mathrm{C}\right)$. Twenty four glass test tubes $(18 \times 180$ $\mathrm{mm}$, with metal cap) for each type of medium were used, one explant per tube. Cultures were incubated at $25 \pm 3^{\circ} \mathrm{C}$, $16 / 8 \mathrm{~h} \mathrm{light/dark}$ period provided by cool-white fluorescent lamps (photosynthetically active radiation with a photon flux density 140 to $160 \mu \mathrm{mol} \mathrm{m} \mathrm{s}^{-2}$ ).

After 48 days in culture, height of the main shoot was measured. Lateral shoots that were longer than $0.5 \mathrm{~cm}$ were also counted and measured. Proliferation rate, represented by a number of plantlets that can be obtained from one initial explant (using main, lateral and adventitious shoots and dividing them) was determined. Number of adventitious roots per plantlet was also measured.

At the end of the experiment, $\mathrm{pH}$ of the each type of medium was measured in triplicate.

Mean values and standard error were calculated for each measured parameter. Analysis of variance between shoots cultured on different type of media was performed using R 3.3.2. (R Core Tam 2016) and Tukey's HSD test (Mendiburu 2016) at $\mathrm{P} \leq 0.05$ level.

\section{Results}

Significant differences in morphogenesis of birch shoot plantlets were observed after 48 days in culture, depending on the type of cytokinin used and their concentration (Fig. 1 to 4$)$. The highest main shoot was observed for explants grown on medium containing BAP $1.0 \mathrm{mg} \mathrm{L}^{-1}(2.65 \pm 0.14$

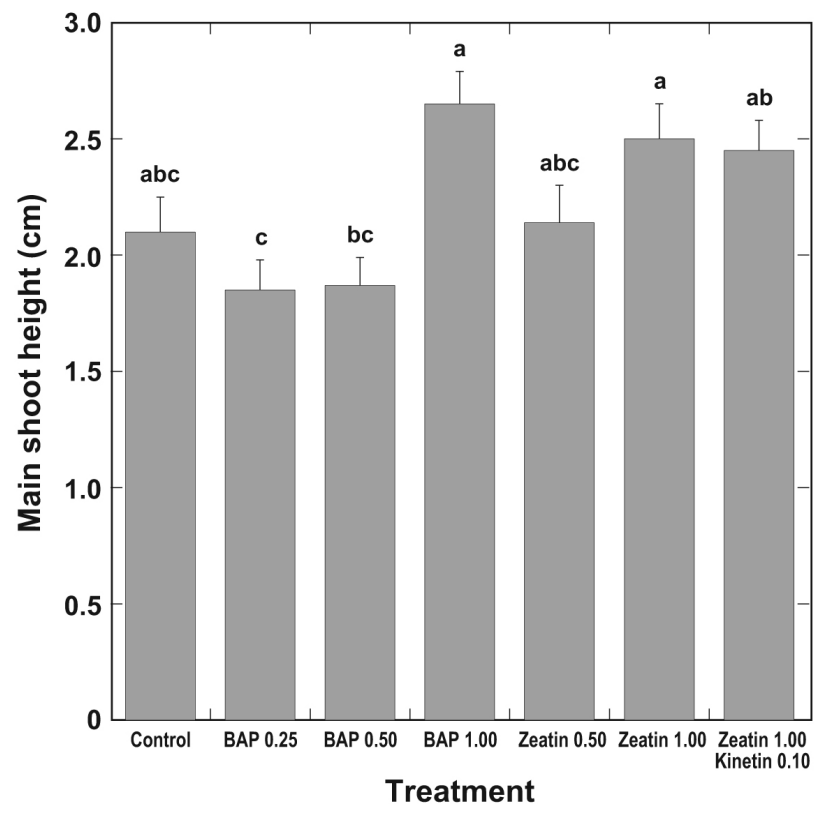

Fig. 1. The height of the main shoot of Betula pendula explants cultured in vitro in dependence on the type and concentration of cytokinins. Means with the same letter are not significantly different $(\alpha=0.05)$. Standard errors are shown.

$\mathrm{cm}$ ), which was significantly higher than that in treatment with BAP 0.25 and $0.5 \mathrm{mg} \mathrm{L}^{-1}$. The height of the main shoot increased when both synthetic and naturally occurring cytokinin concentration in the medium increased (Fig. 1).

Growth of lateral shoots was not observed in the medium

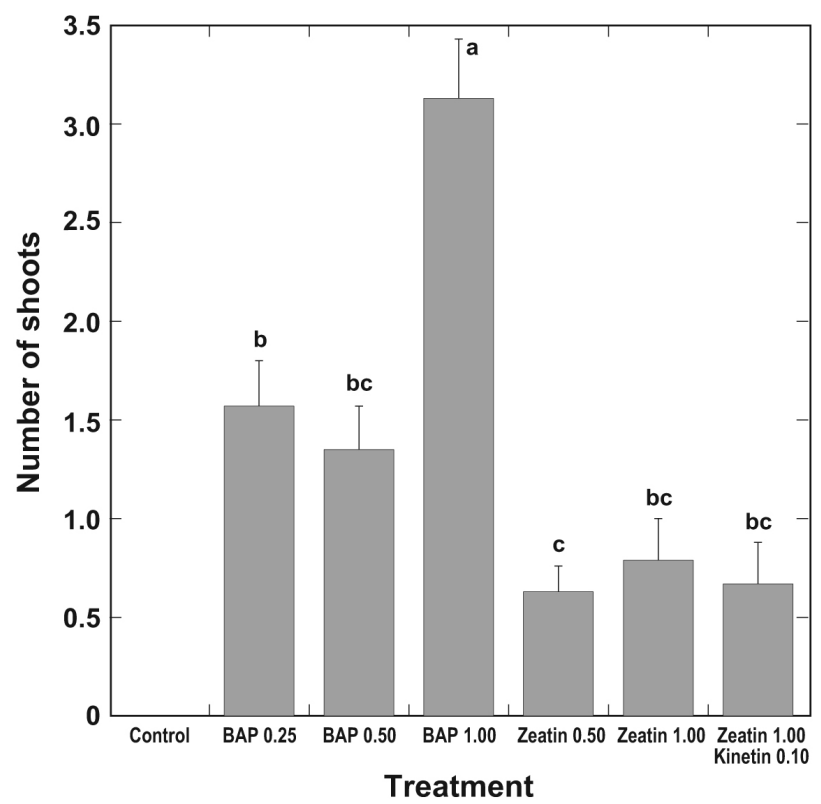

Fig. 2. The mean number of lateral shoot formed on Betula pendula explants cultured in vitro in dependence on the type and concentration of cytokinins. Means with the same letter are not significantly different $(\alpha=0.05)$. Standard errors are shown. 


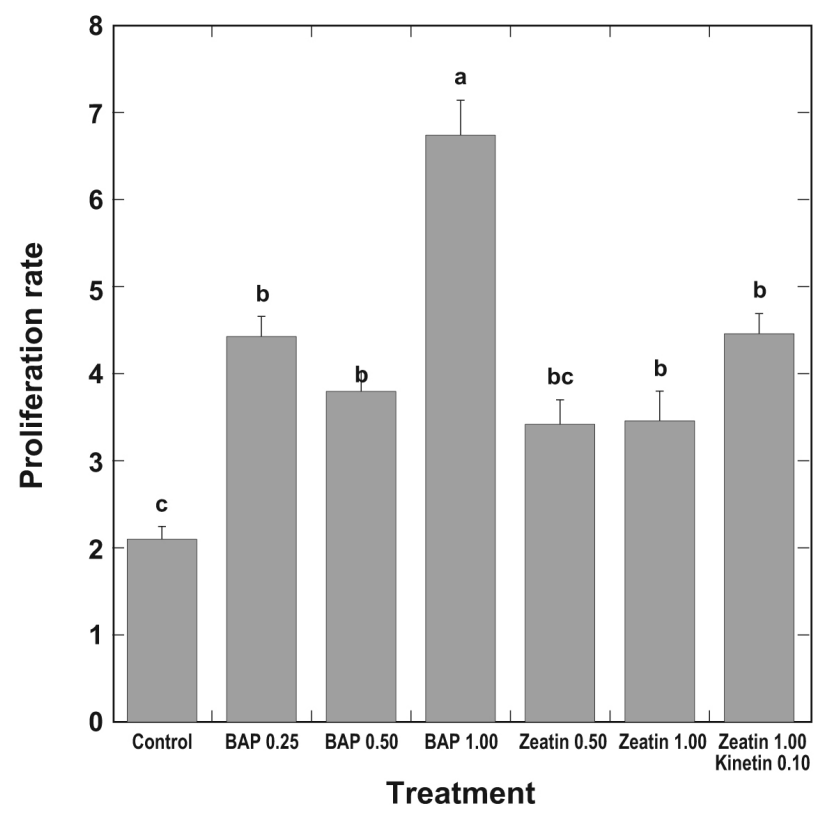

Fig. 3. The mean proliferation rate of Betula pendula explants cultured in vitro in dependence on the type and concentration of cytokinins. Means with the same letter are not significantly different $(\alpha=0.05)$. Standard errors are shown.

without plant growth regulators (Fig. 2). Both synthetic and naturally occurring cytokinins were effective in promoting growth of axillary and adventitious shoots. The largest number of shoots was produced in the medium containing $1.0 \mathrm{mg} \mathrm{L}^{-1}$ BAP $(3.1 \pm 0.3)$, which differed significantly from that on all other media. Synthetic cytokinin BAP was far more effective than zeatin, especially at concentration

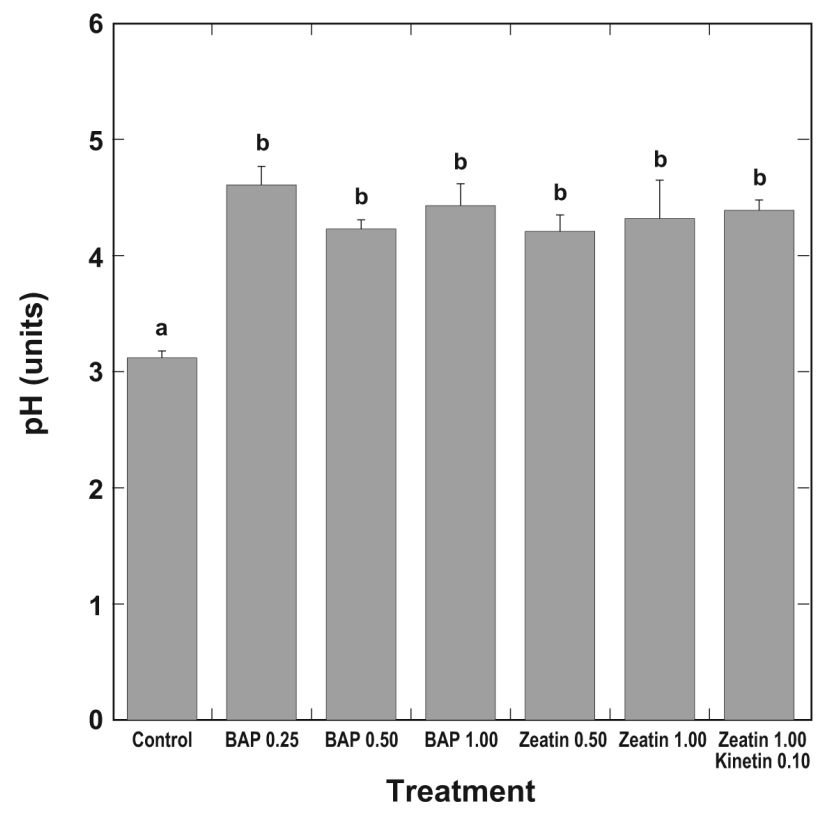

Fig. 5. The mean $\mathrm{pH}$ of the medium in dependence on the type and concentration of cytokinins. Means with the same number are not significantly different $(\alpha=0,05)$. Standard errors are shown.

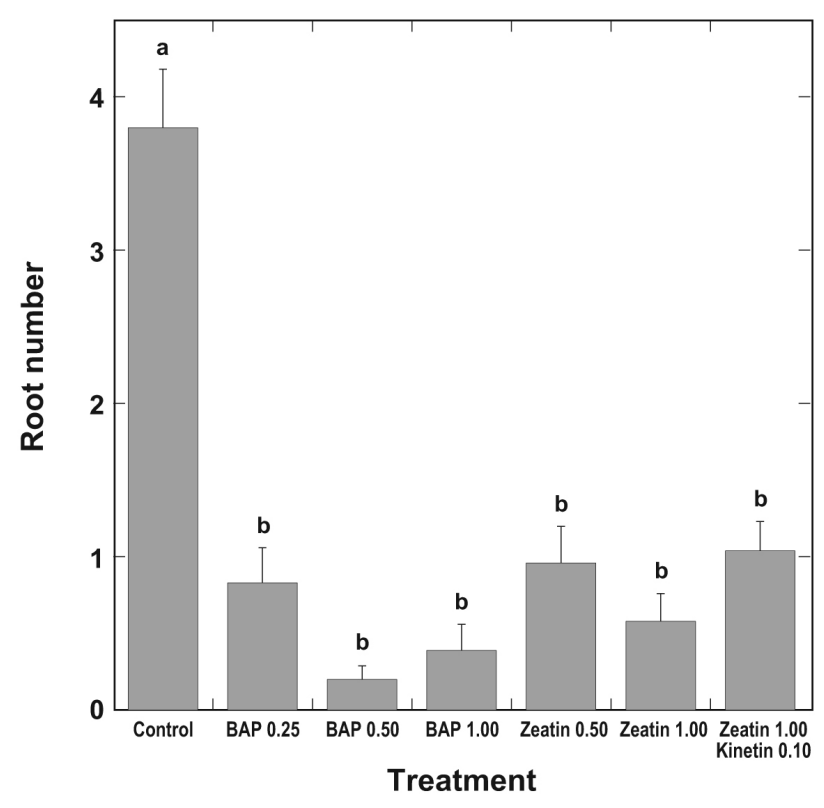

Fig. 4. The mean number of roots of Betula pendula explants cultured in vitro in dependence on the concentration of cytokinins. Means with the same number are not significantly different $(\alpha=$ 0,05). Standard errors are shown.

$1.0 \mathrm{mg} \mathrm{L}^{-1}$. Axillary and adventitious shoot length did not significantly differ among different treatments (data not shown).

Shoot proliferation rate is the most important parameter in the multiplication stage. The best results were obtained using medium supplemented with $1.0 \mathrm{mg} \mathrm{L}^{-1}$ BAP $(6.74 \pm 0.40$ plants per shoot), which was significantly different from that in other media (Fig. 3). Proliferation rate is mostly determined by the number of lateral shoots and as shown earlier, BAP $1.0 \mathrm{mg} \mathrm{L}^{-1}$ was most effective in inducing lateral shoot growth.

All synthetic and natural cytokinins used significantly reduced the number of adventitious roots formed for birch in vitro plantlets (Fig. 4). Shoots cultured on the medium without growth regulators showed very good rooting ability, $3.8 \pm 0.4$ roots per explant (Fig. 4).

There was significantly higher medium $\mathrm{pH}(\sim 4.37)$ for all media containing cytokinins at the end of experiment, as compared with that of medium without growth regulators (pH 3.12; Fig. 5).

\section{Discussion}

Cytokinins play important role in controlling in vitro shoot development. Together with auxins they regulate cell cycle by stimulating G1/S and G2/M transitions (Pasternak et al. 2000). Some of the cytokinin effects on shoot cultures include inhibition of root formation and induction of adventitious and axillary shoot formation (Van Staden et al. 2008). Usually, in vitro shoot length decrease with increasing cytokinin concentration (Jokinen et al. 1991). 
In the present study increasing cytokinin concentration resulted in increased shoot length. Several studies report on cytokinin-induced shoot apical dominance (Vieitez, Vieitez 1980; O’Dowd 2004). For example, longer birch shoots were obtained using $1.0 \mathrm{mg} \mathrm{L}^{-1}$ zeatin with $0.1 \mathrm{mg}$ $\mathrm{L}^{-1}$ kinetin, as compared with the same growth regulators at concentrations 0.25 and $0.025 \mathrm{mg} \mathrm{L}^{-1}$ (O'Dowd 2004).

It is well known that cytokinins along with auxins effectively induce growth of both axillary and adventitious shoots. Usually a narrow range of concentration of cytokinins and auxins is required for obtaining best results (Jain, Häggman 2007; Van Staden et al. 2008). In the present study no exogenous auxins were added. It is most likely that exogenously added cytokinin $1.0 \mathrm{mg} \mathrm{L}^{-1}$ BAP together with existing endogenous auxin concentration resulted in the best proportion for shoot growth (Fig. 1). Dubova (1994) obtained 3.0 to 8.6 birch plants per explant on the medium containing $0.5 \mathrm{mg} \mathrm{L}^{-1} \mathrm{BAP}$ and $0.05 \mathrm{mg} \mathrm{L}^{-1} \mathrm{IBA}$, which is a significantly larger number than that obtained in the present study, but only juvenile shoots were used in the former research. It is well known that age of the mother plant affects the rate of shoot proliferation in culture (McCown 2000). Shoot proliferation rate usually increases with the increase in concentration of cytokinins until a certain threshold is reached (Jokinen et al. 1991). After that many vitrified shoots are produced, which fail to grow. No cytokinin threshold were observed in this study, suggesting that even cytokinin BAP concentration larger than $1.0 \mathrm{mg}$ $\mathrm{L}^{-1}$ could be used for optimal multiplication. In contrast, other studies show that the cytokinin threshold for most plants is at $1.0 \mathrm{mg} \mathrm{L}^{-1}$ (Van Staden et al. 2008).

There is no unanimous opinion and results about which type of cytokinin is more effective in inducing shoot proliferation. Sometimes both natural and synthetic cytokinins mixed together provide the best results (Van Staden et al. 2008). Usually cytokinins at concentration 0.5 to $10 \mathrm{mg} \mathrm{L}^{-1}$ inhibit formation of adventitious roots (BenJaacov et al. 1991). Sometimes cytokinins can even induce formation of adventitious roots, but only low concentrations are effective. In the present study root formation on shoots cultured in media containing cytokinins can be explained by interaction of endogenous auxin, which can cause adventitious roots to form.

The $\mathrm{pH}$ of the medium affects how much explants take up cations and anions, especially nitrate and ammonium ions. When plants take up one equivalent of $\mathrm{NO}_{3}, 1$ to 1.2 proton equivalents are removed from medium. Considering that in the present study medium $\mathrm{pH}$ was 5.8 at the beginning of the experiment for all types of media, and resulting final differences in medium $\mathrm{pH}$ might be due to the plant material requirement for specific anions or their buffering capacity (Fuggi et al. 1981; Shang et al. 1991). Explants without growth regulator treatment had significantly more roots, compared to cytokinin treatment when shoots had callus at their bases, and this difference might be associated with changes in $\mathrm{pH}$ of the media and probably shoot development.

In conclusion, Woody Plant Medium supplemented with BAP $1.0 \mathrm{mg} \mathrm{L}^{-1}$ is suitable for propagation of birch clone Bau-40-17 in vitro. When using naturally occurring cytokinin zeatin, the best results can be obtained using it at $1.0 \mathrm{mg} \mathrm{L}^{-1}$ concentration with additional $0.1 \mathrm{mg} \mathrm{L}^{-1}$ kinetin. The obtained results need to be further tested with other elite birch clones.

\section{References}

Ben-Jaacov J., Ackerman A., Tal E., Jacobs G. 1991. Vegetative propagation of Alberta magna by tissue culture and grafting. HortScience 26: 74.

Chalupa V. 1981. In vitro propagation of birch (Betula verrucosa Ehrh.). Biol. Plant. 23: 472-474.

Dubova I. 1994. In vitro propagation of selected clones of birch Betula pendula. Mežzinātne 37: 28-33. /in Latvian/

Ewald D., Naujoks G., Welander M., Zhu L.H., Hagqvist R., Salonen M., Harrison A. 2002. Micropropagation and birch field trials. In: Welander M., Zhu L.-H. (eds) Proceeding of the workshop on high quality birch clonal propagation and wood properties, Ronneby, Sweden, August 27-28, 2001, 37-46 pp.

Fuggi A., Rugano V.M., Vona V., Rigano C. 1981. Nitrate and ammonium assimilation in algae cell-suspensions and related $\mathrm{pH}$ variations in the external medium, monitored by electrodes. Plant Sci. Lett. 23: 129-138.

Jain M.S., Häggman H. 2007. Protocols of Micropropagation of Woody Trees and Fruits. Springer, Dordrecht, 559 p.

Jokinen K.J., Honkanen J., Seppänen P., Tärmälä T. 1991. Biotechnology of the silver birch (Betula pendula Roth). AgroIndustry Hi-Tech. 4: 23-26.

Lloyd G., McCown B. 1980. Commercially-feasible micropropagation of mountain laurel, Kalmia latifolia, by use of shoottip culture. Combined Proceedings of the International Plant Propagators Society 30: 421-427.

Magnusson V.A., Castillo C.M., Dai W. 2009. Micropropagation of two elite birch species through shoot proliferation and regeneration. Acta Horticult. 812: 223-230.

McCown B.H. 2000. Recalitrance of woody and herbaceous perennial plants: Dealing with genetic predetermines. In Vitro Cell. Dev. Biol. Plant 36: 149-154.

McCown D.D., McCown B.H. 1987. North American hardwoods. In: Bonga J.M., Durzan D.J. (eds) Cell and Tissue Culture in Forestry. Vol. 3. Martinus Nijhoff Publishers, Dordrecht, pp. 247-260.

Mendiburu F. 2016. Agricolae: Statistical Procedures for Agricultural Research. R package version 1.2-4. https:// CRAN.R-project.org/package=agricolae

Murashige T., Skoog F. 1962. A revised medium for rapid growth and bio assays with tobacco tissue cultures. Physiol. Plant. 15: 473-497.

O'Dowd N. 2004. The improvement of Irish birch. Phase 1: Selection of individuals and populations. COFORD, Dublin. $56 \mathrm{p}$.

Pasternak T., Miskolczi P., Ayaydin F., Mészáros T., Dudits D., Feher A. 2000. Exogenous auxin and cytokinin dependent activation of CDKs and cell division in leaf protoplast-derived cells of alfalfa. Plant Growth Reg. 32: 129-141. 
Perez C., Postigo P. 1989. Micropropagation of Betula celtiberica. Ann. Bot. 64: 67-69.

R Core Team 2016. R: A language and environment for statistical computing. R Foundation for Statistical Computing, Vienna, Austria. URL https://www.R-project.org/.

Ryynänen L., Ryynänen M. 1986. Propagation of adult curly-birch succeeds with tissue culture. Silva Fenn. 20: 139-147.

Särkilahti E. 1988. Micropropagation of mature colchicinepolyploid and irradiation-mutant of Betula pendula Roth. Tree Physiol. 4: 173-179.

Shang X.M., Huang J.Y., Haigler C.H., Trolinder N.L. 1991. Buffer capacity of cotton cells and effects of extracellular $\mathrm{pH}$ on growth and somatic embryogenesis in cotton cell suspensions. In Vitro Cell. Dev. Biol. Plant 27: 147-152.

Van Staden J., Zazimalova E., George E.F. 2008. Plant growth regulators II: Cytokinins, their analogues and antagonists. In: George E.F., Hall M.A., De Klerk G.J. (eds.) Plant Propagation by Tissue Culture. Springer, Netherlands, pp. 205-226.

Vieitez A.M., Vieitez M.L. 1980. Culture of chestnut shoots from buds in vitro. Plant Physiol. 55: 83-84.

Welander M. 1993. Micropropagation of birch. In: Ahuja M.R. (ed) Micropropagation of Woody Plants. Kluwer Academic Publishers, The Netherlands, pp. 223-246. 